\title{
Development and validation of Stability Indicating HPLC method for estimation of Embelin in Embelia tsjeriam cottam(Vidanga)
}

\author{
Research Article
}

\section{Sweta V Kulkarni ${ }^{1}$, Mrinalini C Damle ${ }^{1 *}$}

\section{Department of Quality Assurance, AISSMS College of Pharmacy, Kennedy Road, Near, R.T.O., Pune-411001, Maharashtra, India.}

\begin{abstract}
Embelin, is an active phytoconstituent obtained from fruits of Embelia tsjeriam cottam, commonly known as Vidanga. A simple stability indicating HPLC method for the estimation of Embelin has been developed and validated as per ICH Q2A(R1). Sample was eluted using HiQsil $\mathrm{C}_{8}(4.6 \mathrm{~mm} \times 250 \mathrm{~mm})$ column. The mobile phase consisted of Methanol: Acetonitrile: 1\% O-phospheric acid in water in the ratio of 70:15:15 v/v/v which was sonicated to degas and delivered at a flow rate of $1 \mathrm{ml} / \mathrm{min}$ at ambient temperature. The retention time of Embelin was $6.05 \pm 0.2$ minutes. Studies were performed using an HPLC system equipped with a UV detector; the response was monitored at $291 \mathrm{~nm}$. A good linear relationship over the range of $2-10 \mu \mathrm{g} / \mathrm{ml}$ concentrations with correlation coefficient value of 0.999 was obtained. The accuracy of the method is indicated by good recovery in the range of 98.9-101.2\% and precision less than 2\% RSD. The limit of detection and limit of quantification were found to be 0.47 and $1.44 \mu \mathrm{g} / \mathrm{ml}$ respectively. Embelin was subjected to stress conditions as per ICH Q2A(R2) and a significant degradation was found to occur by acid hydrolysis, oxidation and thermal stress. Stress degradation studies on embelin provide an insight into its stability.
\end{abstract}

Keywords: Embelia tsjeriam cottam, Embelin, Stability indicating HPLC, Validation, stress degradation

\section{Introduction}

Herbal medicines are getting popularized in developing and developed countries owing to its natural origin and lesser side effects. Chemical fingerprints obtained by chromatographic techniques are strongly recommended for the purpose of quality control of herbal medicines, since they represent appropriately the "chemical integrities" of the herbal medicines and therefore be used for authentication and identification of the herbal products.

Embelin (2, 5-dihydroxy-3-undecyl-pbenzoquinone), is an active principle of Embelia tsjeriam cottam commonly known as vidanga. Vindanga is official in Indian pharmacopia 2014(1) and Ayurvedic Pharmacopia (2). Embelia tsjeriam cottam belonging to the family Myrsinaceae, is a climber found in the Western Ghats of Lonavala and also seen in the southern states of Maharashtra, Karnataka, Kerala, Tamil Nadu

*Corresponding Author:

Mrinalini. C Damle

Department of Quality Assurance,

AISSMS College of Pharmacy,

Pune - 411001, Maharashtra, India.

Email:mcdamle@rediffmail.com

Phone. No. - 9860230912

Fax No. - +91-020-26058208 and Andhra Pradesh upto an altitude of $1600 \mathrm{~m}$. The fruits of this plant contain (2.5-3.1\%) embelin on dry weight basis. Embelin shows diverse pharmacological activities including chemo prevention in hepato $\square$ carcinogenesis observed in Wistar rats(4), antifertility effects(5), wound healing(6), antibacterial $(3,7)$, free radical scavenging $(8)$ and in vitro cytotoxic activity (9)

Literature survey reveals UV spectrophotometric method reported for the estimation of Embelin in plant and in pharmaceutical dosage form(10-11),HPLC(1214,16) and HPTLC(15).In the present study, HPLC method have been developed as chemical fingerprints for Vidanga extract and Vidanga churna formulation using Embelin as an active chemical marker and to observe the effect of various stress conditions on Embelin.

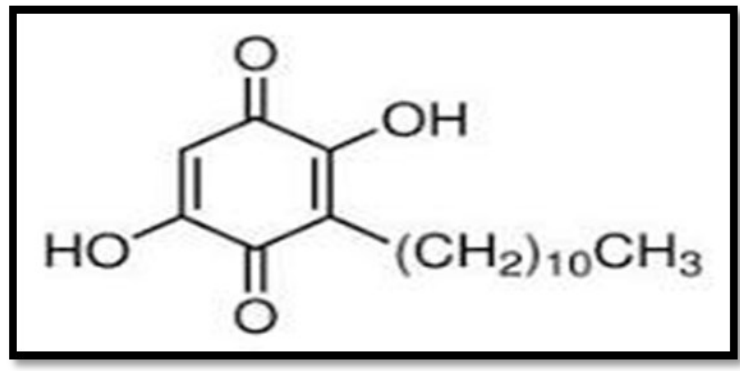

Fig.1:Chemical structure of Embelin 


\section{Materials and Methods}

\section{Chemical and Reagents:}

Vidanga berries and Embelin was purchased from Yucca enterprises, Mumbai and was used as such, without any further purification. Methanol (HPLC), Acetonitrile (HPLC grade), o-phosphoric acid, were purchased from S. D. fine chemical Laboratories, Mumbai. Hydrochloric acid $(\mathrm{HCl})$, hydrogen peroxide $\left(\mathrm{H}_{2} \mathrm{O}_{2}, 3 \% \mathrm{v} / \mathrm{v}\right)$ and sodium hydroxide $(\mathrm{NaOH})$ were purchased from LOBA CHEMIE PVT. LTD., Mumbai.

\section{Equipment:}

Quantitative HPLC was performed using isocratic high performance liquid chromatography (Jasco HPLC system) with a LC-PU 2080 Plus pump, manual injector with loop volume of $20 \mu \mathrm{L}$ (Rheodyne), programmable MD 2010 UV detector and HiQsil C8 Column (250 mm x $4.6 \mathrm{~mm}, 5 \mu \mathrm{m}$ particle size). The HPLC system was equipped with "Borwin- UV software (version1.5) software. An electronic balance (Shimadzu AY-120), UV-Visible (Jasco model V-550) spectrophotometer, Elga Labwater (PURELAB UHQ-II) water purification system were used in this study.

\section{Optimized Chromatographic conditions:}

Embelin was analyzed using various mobile phases like water and methanol, Acetonitrile and water in varying proportion. After several trials, Methanol: Acetonitrile: $1 \%$ o-phospheric acid in water in the ratio of $70: 15: 15 \mathrm{v} / \mathrm{v} / \mathrm{v}$ was selected as the mobile phase. Analysis was performed on HiQsil $\mathrm{C}_{8}$ column $(250 \times 4.6$ $\mathrm{mm}$ i.d, $5 \mu \mathrm{m}$ ) which gave good resolution and acceptable system suitability parameters. The flow rate of mobile phase was maintained at $1 \mathrm{ml} / \mathrm{min}$ and the response was monitored at $291 \mathrm{~nm}$ with a run time of 10 $\min$.

\section{Preparation of Standard stock solution:}

Standard stock solution was prepared by dissolving $10 \mathrm{mg}$ of Embelin in $10 \mathrm{ml}$ of methanol to get concentration of $1000 \mu \mathrm{g} / \mathrm{ml}$. From the standard stock solution, working standard solution was prepared containing $100 \mu \mathrm{g} / \mathrm{ml}$ of Embelin.

\section{Preparation of Extract solution:}

The $50 \mathrm{~g}$ coarse sized dried berries powder was weighed and used for the extraction by using maceration technique and separately using the soxhlet apparatus for 5 cycles. Solvent used was Ethyl alcohol The extract was concentrated on water bath at $50^{\circ} \mathrm{C} . \%$ yield obtained was $9 \%$.The assay was carried out by weighing $0.25 \mathrm{~g}$ of extract and dispersed in $10 \mathrm{ml}$ of methanol which was diluted further to get concentration of $2.5 \mathrm{ug} /$ ml solution.
Preparation of sample solution (Formulation Analysis):

Formulation analysis is carried out as per label claim of the marketed formulation (Vidanga Ghana) which is claimed to contain $250 \mathrm{mg}$ of aqueous extract of vidanga. The assay was carried out by weighing tablet equivalent to $0.25 \mathrm{~g}$ of extract in $10 \mathrm{ml}$ of methanol which was diluted further to get a concentration of $2.5 \mathrm{ug} / \mathrm{ml}$ extract solution.

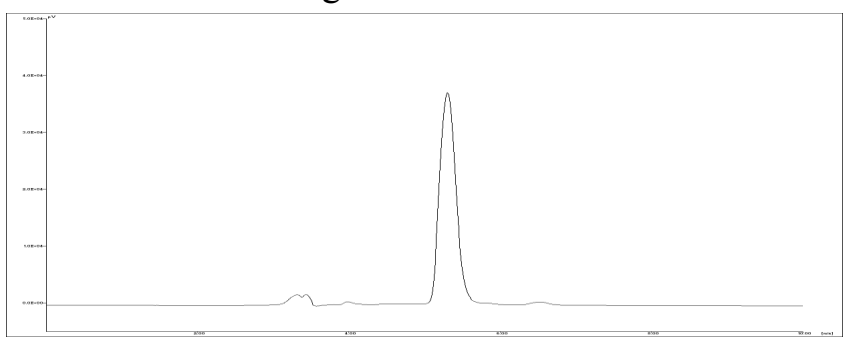

Fig.2: Chromatogram of Methanol: ACN: 1\% ophosphoric acid in water (70:15:15v/v/v)

The system suitability parameter is given in Table. 1 below

Table.1: System suitability parameter

\begin{tabular}{|c|c|c|c|c|c|}
\hline Name & $\begin{array}{c}\text { RT } \\
(\mathbf{m i n})\end{array}$ & $\begin{array}{c}\text { Conc } \\
\cdot(\boldsymbol{\mu g} / \\
\mathbf{m l})\end{array}$ & $\begin{array}{c}\text { Area } \\
(\boldsymbol{\mu V} . \\
\mathbf{S e c})\end{array}$ & Plates & $\begin{array}{c}\text { Asym } \\
\text { metry }\end{array}$ \\
\hline Embelin & $\begin{array}{c}6.05 \\
\pm 0.3\end{array}$ & 4 & 383203 & 2204 & 1.01 \\
\hline
\end{tabular}

\section{Stress degradation studies}

Stress degradation studies were carried under condition of acid/ base/ neutral hydrolysis, oxidation, dry heat and photolysis. For each study, samples were prepared as per ICH Q1A(R2)(17) using HighPerformance liquid chromatography (HPLC) analysis. The endeavor was to quantify degradation of embelin under various stress conditions.

\section{Acidic degradation}

Acid induced degradation was performed by adding $1 \mathrm{ml}$ of $0.01 \mathrm{~N}$ Hydrochloric acid $(\mathrm{HCl})$ to volumetric flask containing $1 \mathrm{ml}$ of Embelin standard solution $(100 \mu \mathrm{g} / \mathrm{ml})$. The volume was made up to $10 \mathrm{ml}$ with methanol \& kept for $24 \mathrm{hrs}$ in dark place. The solution was neutralized with Sod. Hydroxide solution. Final solution $(10 \mu \mathrm{g} / \mathrm{ml})$ was injected into the HPLC system.

\section{Alkaline degradation}

Base induced degradation was performed by adding $1 \mathrm{ml}$ of $0.1 \mathrm{~N}$ Sodium hydroxide $(\mathrm{NaOH})$ to volumetric flask containing $1 \mathrm{ml}$ of Embelin standard solution $(100 \mu \mathrm{g} / \mathrm{ml})$. The volume was made up to $10 \mathrm{ml}$ with methanol \& kept for $24 \mathrm{hrs}$ in dark place. The solutions were processed in the same way as acid degradation and neutralized with hydrochloric acid before injection. 
Neutral hydrolysis

Neutral hydrolysis was performed by adding $1 \mathrm{ml}$ of Embelin standard solution $(100 \mu \mathrm{g} / \mathrm{ml})$ was mixed with $1 \mathrm{ml}$ of water in $10 \mathrm{ml}$ of volumetric flask and the volume was made upto the mark with methanol. Solution was kept for $24 \mathrm{hrs}, 1 \mathrm{ml}$ of neutral stressed solution $(100 \mu \mathrm{g} / \mathrm{ml})$ diluted with mobile phase and volume made up to $10 \mathrm{ml} .20 \mu \mathrm{l}$ aliquots was injected into HPLC system.

\section{Oxidative degradation}

Oxidative degradation was performed by adding $1 \mathrm{ml}$ of Hydrogen peroxide $\left(\mathrm{H}_{2} \mathrm{O}_{2}, 3 \% \mathrm{v} / \mathrm{v}\right)$ to volumetric flask containing $1 \mathrm{ml}$ of Embelin standard solution $(100 \mu \mathrm{g} / \mathrm{ml})$. The volume was made up to $10 \mathrm{ml}$ with methanol \& kept for $6 \mathrm{hrs}$ in dark place.

\section{Degradation under dry heat (thermal degradation)}

Dry heat degradation was performed by adding 1 $\mathrm{ml}$ of the standard Embelin to $1 \mathrm{ml}$ of dry heat exposed Embelin solution $(100 \mathrm{ug} / \mathrm{ml})$ which was placed in an oven at $80^{\circ} \mathrm{C}$ for $8 \mathrm{hrs}$. The solution were mixed in 10 $\mathrm{ml}$ volumetric flask and volume was made with mobile phase, $20 \mu 1$ was injected into HPLC system.

\section{Photo-stability studies (18)}

For photo stability study, the standard drug was exposed to UV light up to 200 watt hours/square meter and subsequently to cool fluorescent light to achieve an illumination of 1.2 million Lux.Hr. Sample was weighed, dissolved and diluted, $1 \mathrm{ml}$ of photo exposed drug solution $(100 \mu \mathrm{g} / \mathrm{ml})$ and $1 \mathrm{ml}$ of standard Embelin were mixed in $10 \mathrm{ml}$ volumetric flask and volume was made with mobile phase. Then analyzed under the optimized chromatographic conditions.

\section{Validation of Analytical method}

The method was validated as per ICH Q2 (R1) guidelines (19)

\section{Specificity}

The specificity was carried out to determine whether there are any interference of any impurities (presence of components may be expected to be present). The specificity of the method was ascertained by peak purity profiling studies.

\section{Linearity and Range}

It is the ability to attain test results that are directly proportional to the concentration of analyte in the sample. From the standard stock solution $(1000 \mu \mathrm{g} /$ $\mathrm{ml}$ ), the linearity of the method was established by a spotting a series of sample of Embelin, the solutions of five different concentration levels $2-10 \mu \mathrm{g} / \mathrm{ml}$ was injected. Calibration curves for the standard Embelin were constructed by plotting the peak area against their respective concentrations. Linear regression was applied and slope, intercept, and correlation coefficient-
$\mathrm{R}^{2}$ were determined five replicates per concentration were injected. The linearity (relationship between peak area and concentration) was determined

\section{Accuracy}

Accuracy is determined in terms of percentage recovery. The accuracy study was performed at $80 \%$, $100 \%$ and $120 \%$ for Embelin. Standard and sample solutions were applied to TLC plate in triplicate and percentage recoveries of Embelin were calculated. The area of every level was used for calculation of $\%$ recovery.

\section{Assay}

The raw material and marketed formulation of Vidanga were selected for the assay method.

\section{Assay of Embelin from Formulation}

The assay was carried out by weighing tablet equivalent to $0.025 \mathrm{~g}$ of extract in $10 \mathrm{ml}$ of methanol from which $5 \mathrm{ml}$ of solution was diluted to get a concentration of extract solution Analysis was repeated for three times. Sample solution was injected and area was recorded. Concentration and \% assay was calculated.

\begin{tabular}{|c|c|c|c|}
\hline $\begin{array}{c}\text { Formula } \\
\text { tion } \\
\text { Name }\end{array}$ & Manufacturer & Mfg. Date & Expiry Date \\
\hline $\begin{array}{c}\text { Vidanga } \\
\text { Ghana }\end{array}$ & Chaitanya & September & September \\
& Pvt,ltd & 12,2014 & 15,2015 \\
& & & \\
\hline
\end{tabular}

Assay of Embelin from Extract

Assay of extract was done by weighing $0.25 \mathrm{~g}$ of extract in $10 \mathrm{ml}$ of methanol. From which $0.1 \mathrm{ml}$ was further diluted to $10 \mathrm{ml}$ and further to get a concentration of $2.5 \mathrm{ug} / \mathrm{ml}$. Analysis was repeated for three times. Sample solution was injected and area was recorded. $\%$ assay was determined from linearity equation.

\section{Precision}

Express the closeness of agreement between the series of measurement obtained from multiple sampling of same homogeneous sample under the prescribed conditions. System precision was determined in terms of repeatability.

\section{Intraday precision:}

Precision of the system was evaluated by analyzing six independent standard solutions of $2 \mathrm{ug} / \mathrm{ml}$ and the peak area was determined and expressed as a mean and \%RSD calculated from the data obtained.

\section{Interday precision:}

Precision of the system was evaluated by analyzing three independent standard preparations on 
three different days and \%RSD calculated from the data obtained.

\section{Limit of Detection (LOD) and Limit of Quantitation (LOQ)}

LOD and LOQ were calculated by using the formula:

$\mathrm{LOD}=3.3(\mathrm{SD}) / \mathrm{S}$ and $\mathrm{LOQ}=10(\mathrm{SD}) / \mathrm{S}$,

Where $\mathrm{SD}=$ the standard deviation of response of Embelin area for the lowest conc. in the range and $\mathrm{S}=$ the slope of the calibration curve.

\section{Robustness:}

Robustness of the method was determined by carrying out the analysis under conditions during which wavelength, flow rate were altered and the effects on the area were noted.

\section{RESULTS AND DISCUSSION}

Stress degradation studies:

The results of stress degradation studies are summarized below;

\section{Acid Hydrolysis}

Degradant was observed at a Rt of 6.7 with percent recovery of $76.94 \%$.

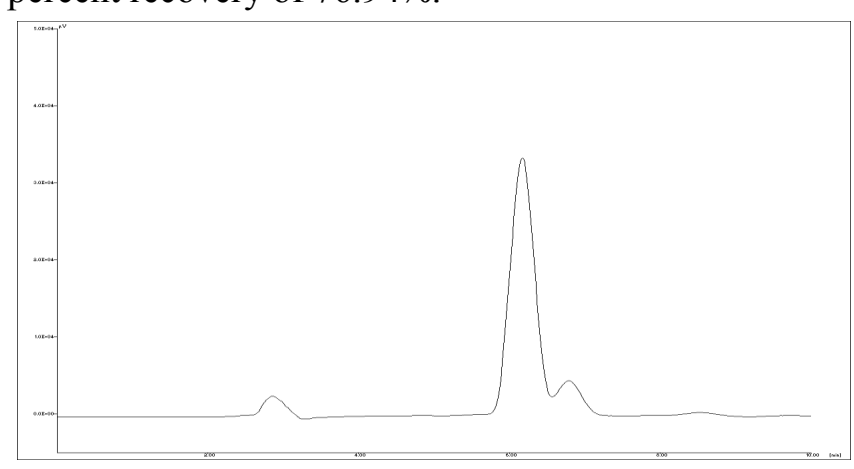

Fig.3: Chromatogram of Acid treated Embelin $(10 \mu \mathrm{g} / \mathrm{ml})$.

\section{Oxidative Degradation}

Degradant was observed at a $\mathrm{Rt}$ of 3.4 with percent recovery of $75.29 \%$.

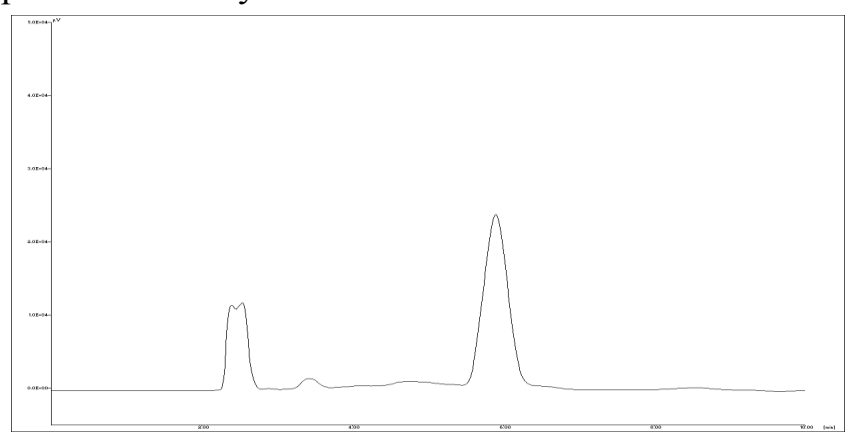

Fig.4: Chromatogram of $\mathrm{H}_{2} \mathrm{O}_{2}$ treated Embelin $(10 \mu \mathrm{g} / \mathrm{ml})$.

\section{Dry heat Degradation}

Degradant was observed at Rt of 4.2 with percent recovery of $79.22 \%$

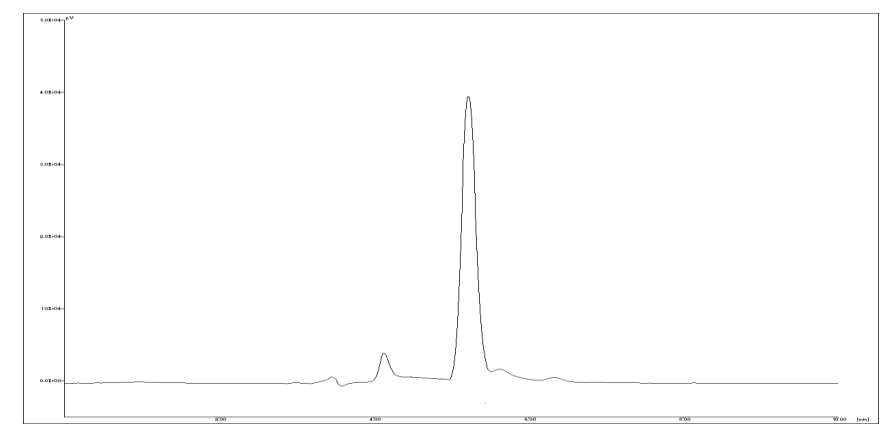

Fig.5: Chromatogram of Dry heat treated Embelin $(10 \mu \mathrm{g} / \mathrm{ml})$.

\section{Alkali Degradation}

Average $83.50 \%$ of Embelin was recovered with no peak of degradation in alkaline condition.

\section{Photolytic Degradation}

Average $82.63 \%$ of Embelin was recovered with no peak of degradation after photolytic degradation.

\section{Neutral Degradation}

Average $87.63 \%$ of Embelin was recovered with no peak of degradation in neutral condition.

Table.2: Summary of Stress degradation studies

\begin{tabular}{|c|c|c|c|}
\hline $\begin{array}{c}\text { Stress } \\
\text { Degradation } \\
\text { Condition }\end{array}$ & Peak Area & $\begin{array}{c}\% \\
\text { Recovery }\end{array}$ & $\begin{array}{c}\text { Rt of } \\
\text { degradatio } \\
\text { n product }\end{array}$ \\
\hline $\begin{array}{c}\text { Base }(0.1 \mathrm{~N} \\
\text { NaOH, kept } \\
\text { for } 24 \text { hrs) }\end{array}$ & 838662 & 83.50 & - \\
\hline $\begin{array}{c}\text { Acid }(0.1 \mathrm{~N} \\
\mathrm{HCl} \text { kept for } \\
24 \text { hrs })\end{array}$ & 775116 & 76.94 & 6.7 \\
\hline $\begin{array}{c}\text { Neutral (kept } \\
\text { for 24hr) }\end{array}$ & 882513 & 87.63 & - \\
\hline $\begin{array}{c}\mathrm{H}_{2} \mathrm{O}_{2} 3 \% \\
\text { (kept for } 6 \\
\text { hrs) }\end{array}$ & 758524 & 75.29 & 3.4 \\
\hline $\begin{array}{c}\text { Heat dry } \\
\text { (60 }{ }^{\circ} \mathrm{C}, 8 \text { hrs) }\end{array}$ & 798023 & 79.22 & 4.2 \\
\hline $\begin{array}{c}\text { Photo stability } \\
\text { (UV, 200 watt } \\
\text { hrs/square } \\
\text { meter and } \\
\text { Florescence } \\
1.2 \text { million } \\
\text { Lux. Hrs) }\end{array}$ & 832256 & 82.63 & - \\
\hline
\end{tabular}


The results of stress degradation studies of Embelin obtained by us fairly match the ones reported by Ferreira G and Laddha KS[16].

The results indicate that Embelin is prone to oxidative, thermal and acid hydrolytic degradation. A well resolved product of degradation was obtained under these conditions. This method can distinguish between standard and degraded Embelin.

\section{Validation of analytical method \\ Specificity:}

The peak purity values were found to be more than 980, indicating the non interference of any other peak of degradation product, impurity or matrix.

\section{Linearity and Range:}

In the linearity parameter calibration curve was constructed by plotting peak area against respective concentration of Embelin. The plots were found to be linear in the range of $2-10 \mu \mathrm{g} / \mathrm{ml}$ with coefficient of correlation (r2) 0.999 for Embelin as shown in Table 3 below.

\section{Fig.6: Chromatogram of Linearity of Embelin}

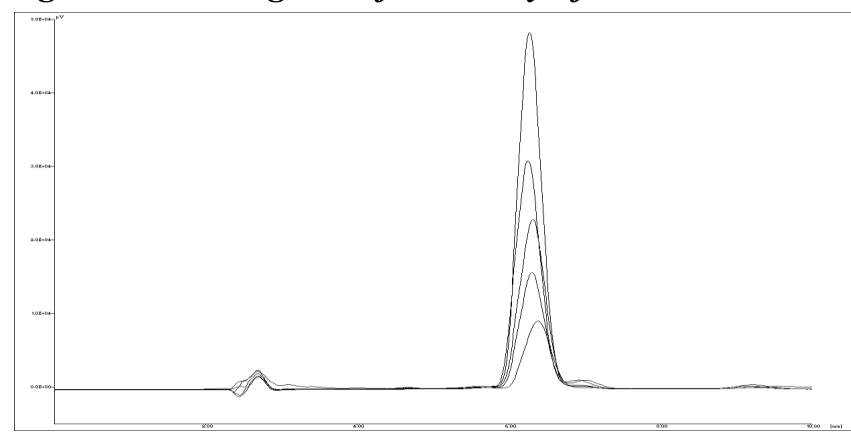

Table.3: Linearity study of Embelin

\begin{tabular}{|c|c|c|}
\hline Sr.no. & $\begin{array}{c}\text { Conc } \\
(\boldsymbol{\mu g} / \mathbf{m l})\end{array}$ & Peak Area \\
\hline 1 & 2 & 216714 \\
\hline 2 & 4 & 392519 \\
\hline 3 & 6 & 585241 \\
\hline 4 & 8 & 783059 \\
\hline 5 & 10 & 978647 \\
\hline
\end{tabular}

Fig.7: Calibration curve of Embelin

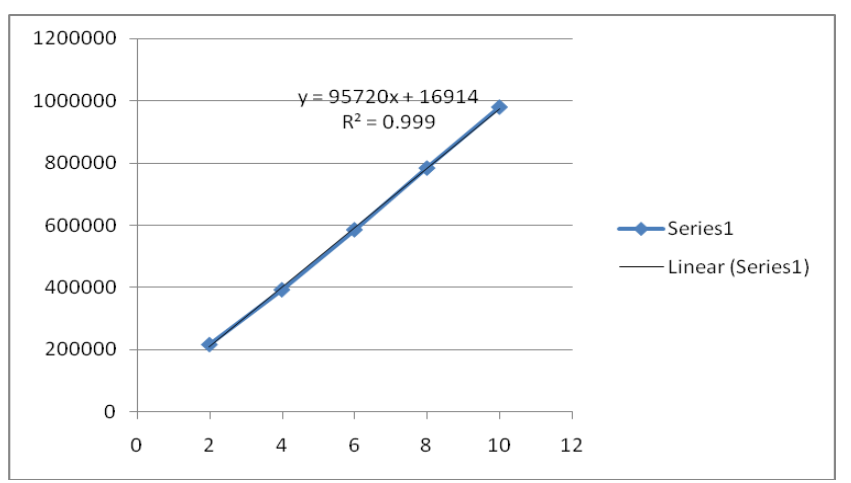

Accuracy

To check the accuracy of the method, recovery studies were carried out by addition of standard marker solution to pre-analyzed sample solution at three different levels $80 \%, 100 \%$ and $120 \%$. The percentage recovery was found to be in a range of $98.9-101.2 \%$.

Assay

The raw material and marketed formulation of Vidanga were selected for the assay method.

Assay of Formulation

Table.4: Assay for Embelin from Vidanga Ghana

\begin{tabular}{|c|c|c|}
\hline $\begin{array}{c}\text { Injected Sample } \\
(\boldsymbol{\mu} \mathbf{g} / \mathbf{m l})\end{array}$ & Area & \% Assay \\
\hline 2.5 & 228531 & 0.88 \\
\hline 2.5 & 226538 & 0.87 \\
\hline 2.5 & 228918 & 0.88 \\
\hline
\end{tabular}

Assay of Raw material

Table.5: Assay for Embelin from Vidanga extract

\begin{tabular}{|c|c|c|}
\hline $\begin{array}{c}\text { Injected Sample } \\
(\boldsymbol{\mu g} / \mathbf{m l})\end{array}$ & Area & \% assay \\
\hline 2.5 & 273231 & 1.07 \\
\hline 2.5 & 270282 & 1.05 \\
\hline 2.5 & 272699 & 1.06 \\
\hline
\end{tabular}

\section{Precision}

The Intraday precision was found to be 0.66 . Interday precision was calculated at three levels 2,4,6ug/ $\mathrm{ml}$ which was found to be $0.56 \%, 0.78 \%, 1.68 \%$.Thus the Intraday and Interday precision were found to be within the limits.

\section{Limit Of Detection(LOD) and Limit Of Quantitation (LOQ)}

The LOD and LOQ values were found to be 0.47 and $1.44 \mu \mathrm{g} / \mathrm{ml}$ respectively.

\section{Robustness:}

Robustness of the method was determined by carrying out the analysis under conditions during which wavelength, flow rate were altered and the effects on the area were noted. The \% RSD was found to be within the limits and the method was found to be robust. 
Mrinalini C Damle et.al., Estimation of Embelin in Embelia tsjeriam cottam

Table.6: Summary of validation parameters

\begin{tabular}{|c|c|c|}
\hline Sr.no. & Validation parameter & Embelin \\
\hline 1. & $\begin{array}{c}\text { Linearity Equation (r2) } \\
\text { Range }\end{array}$ & $\begin{array}{c}\mathrm{Y}=95720 \mathrm{x}-16914 \\
\mathrm{r}^{2}=0.999\end{array}$ \\
\hline 2. & Precision (\% RSD ) & \\
\cline { 2 - 3 } & Intraday & $0.66 \%$ \\
\cline { 2 - 3 } & Interday & $1.17 \%$ \\
\hline 3. & Accuracy & \\
\cline { 2 - 3 } & 80 & $101.2 \%$ \\
\cline { 2 - 3 } & 100 & $99.7 \%$ \\
\cline { 2 - 3 } & 120 & $98.90 . \%$ \\
\hline 4. & Limit of Detection & $0.47 \mathrm{ug} / \mathrm{ml}$ \\
\hline 5. & Limit of Quantification & $1.44 \mathrm{ug} / \mathrm{ml}$ \\
\hline 6. & Specificity & Specific \\
\hline 7. & Robustness & Robust \\
\hline
\end{tabular}

\section{Conclusion}

The developed method was found to have all parameters within limits of ICH guidelines. When exposed to stress conditions Embelin was found to be very much susceptible to Acidic, Oxidative and Dry heat condition. Since the stress degradation products of Embelin are well resolved, this method has stability indicating property. It may be used in phytopharmaceuticals formulation industry to monitor the stability of active marker compound, to analyse the plants for Embelin content before taking up the production. Since the reported method involves a higher percentage of costly solvent Acetonitrile, our developed method is cost effective Hence our validated HPLC method can serve as a Quality control parameter for herbal raw materials containing Embelin and can be readily adapted for routine analysis of Embelin.

\section{Acknowledgement}

The authors would like to thank the Principal and Management, AISSMS College of Pharmacy, Pune for providing required facilities for research work.

\section{References}

1. The official compendia of standards, Indian Pharmacopoeia, volume-III, New Delhi, controller of publication.2014; 750 .

2. The Ayurvedic Pharmacopoeia of India. Ministry of health and family welfare, Part-I, Vol-I. 163165.

3. Thorat K, Pokhriyal B, Patilanti L. Microbial activity of extracts of leaf and roots of Embelia tsjeriam cottam against dental pathogens international journal of comprehensive pharmacy. 2012;03(03);1-3.
4. Podolak I, Galanty A, Janeczko Z. Cytotoxic activity of embelin from Lysimachiapunctata. Fitoterapia. 2005; 76;333-35.

5. Prakash A. Antifertility Investigations on Embelin - an Oral Contraceptive of Plant Origin. Part I. Journal of medicinal plant research.1981; 41;25966.

6. Kumara Swamy HM, Krishna V, Shankarmurthy K, Abdul Rahiman B, Mankani KL, Mahadevan KM. Wound healing activity of embelin isolated from the ethanol extract of leaves of Embelia ribes Burm. J Ethnopharmacology. 2007; 109;529 $\square 3$.

7. Chitra M, Devi CS, Sukumar E. Antibacterial activity of embelin. Fitoterapia. 2003; 74;401 $\square 3$.

8. Joshi R, Kamat JP, Mukherjee T. Free radical scavenging reactions and antioxidant activity of embelin: Biochemical and pulse radiolytic studies. ChemBiol Interact. 2007; 167;125 $\square 34$.

9. Jime'nez $\square$ Alonso S, Cha'vez H, Este'vez $\square$ Braun A, Ravelo AG, Feresin G, Tapia A. An efficient synthesis of embelin derivatives through domino Knoevenagel hetero Diels-Alder reactions under microwave irradiation Tetrahedron. 2008; $64 ; 8938 \square 42$.

10. Babu Ganesana, Perumalb P, Manickamb VB et al. Optimization of extraction conditions for embelin in Embelia ribes by UV Spectrophotometry. Scholars Research Library Archives of Applied Science Research. 2010; 2 (2); 49-53.

11. Pathan IK, Patel RK, Bhandari A. Standardization development and validation of spectrophotometric method for simultaneous estimation of embelin and gallic acid as individual and in combination in ayurvedic churna formulation. Asian journal of pharmaceutical and clinical research.2013; 6 (5);170-75.

12. M.C.Damle, S.V.Kulkarni. Development and validation of stability indicating HPTLC method for estimation of Embelin in Embelia tsjeriam cottam, International Journal of Pharmaceutical Science and Drug Research. 2015; 7(3);211-216

13. Nagamani V, Sabitha Rani A, Satyakala M, Reddy C. High performance liquid chromatography (HPLC) analysis of embelin in different samples of Embelis ribes Burm. f. - a threatened medicinal plant of India. Journal of Medicinal Plants Research.2013; 7(24);1761-67.

14. Patel RK, Patel VR, Patel MG. Development and validation of a RP-HPLC method for the simultaneous determination of Embelin, Rottlerin and Ellagic acid in Vidangadi churna. Journal of Pharmaceutical Analysis. 2012; 2(5);366-371.

15. Sudani RJ, Akbari BV, Vidyasagar G, Sharma P. Development and Validation of HPTLC Method for Simultaneous Quantitation of Embelin and Assay of Marketed Formulation. International 
International Journal of Ayurvedic Medicine, 2015, 6(3), 243-249

Journal of Pharmaceutical \& Biological Archives. 2011; 2(2); 652-65.

16. Ferreira G and Laddha KS. Stress Degradation Studies on Embelin, Indian Journal of Pharmaceutical Sciences.2013; 75(2);246-250.

17. ICH, Q1A (R2): Stability Testing of New Drug Substances and Products, ICH Harmonized Tripartite Guideline, Geneva Switzerland. 2003.
18. ICH, Q1B: Stability Testing: Photostability Testing of New Drug Substances and Products, ICH Harmonized Tripartite Guideline, Geneva Switzerland. 2003.

19. ICH Q2 (R1): Validation of Analytical Procedures, Text and Methodology, ICH Harmonized Tripartite Guideline, Geneva Switzerland.2003. 